\title{
Skinks occur on Terre-de-Bas, Les Saintes (Guadeloupe, French West Indies)
}

\author{
Nicolas Barré ${ }^{1, *}$, Antoine Trillot ${ }^{1}$, and Olivier Lorvelec ${ }^{1,2}$
}

'AEVA, Association pour l'Étude et la protection des Vertébrés et végétaux des petites Antilles, 97170 Petit Bourg, Guadeloupe, France. ${ }^{2} E S E$, Écologie et Santé des Écosystèmes, INRA, Agrocampus Ouest, 35042 Rennes, France.

${ }^{*}$ Corresponding author (belairbarre@hotmail.fr)

Date of publication: 17 August 2016.

Citation: Barré N, Trillot A, Lorvelec O (2016) Skinks occur on Terre-de-Bas, Les Saintes (Guadeloupe, French West Indies). Caribbean Herpetology, 56:1-2.

Native skinks (Squamata, Mabuyidae) of the Caribbean islands are threatened with extinction because of the introduction of the Small Indian Mongoose (Urva auropunctata) and many species have been extirpated from portions of their range, or have disappeared entirely (Hedges and Conn, 2012). For this reason, observations of surviving skink populations are important for conservation purposes.

Les Saintes is a Guadeloupean micro-archipelago, located south of Basse-Terre and comprising two main islets, Terre-de-Bas and Terre-de-Haut. They are 850 meters apart and 6.8 and $6.0 \mathrm{~km}^{2}$ in area, respectively, with several smaller islets. The Small Indian Mongoose is absent from Les Saintes. The first mention of skinks in Les Saintes was by Lazell (1973) who noted their presence without detail of date, islet, or circumstance. The recent (2014) discovery of a small (5 individuals) skink population on Terre-de-Haut of Les Saintes (Angin et al. 2015; Angin \& Gomès 2015) and the discovery of a specimen collected in 2010 on Terre-de-Bas of Les Saintes and preserved in rum (Angin et al. 2015, Gomès \& Ibéné 2015) confirm that skinks occur in Les Saintes.

After these recent reports, and because skinks have not been observed previously on Terre-de-Bas of Les Saintes despite regular visits, the possibility arose that they may no longer occur on that islet. However, finding skinks, especially when rare, is often difficult, and deciding if they are present or have disappeared is a challenge. During July 2016, we slowly walked the trails of Terre-de-Bas to search for skinks, covering a total of $34 \mathrm{~km}$ in 22 hours, during mornings (07:30-11:30), in forests and in open and mixed habitats. On July 9th we went through old pastures and cotton-indigo fields covered with Sporobolus grass and scattered with blocks or piles of stones, in the process of recolonization by the native tree species Guettarda scabra, Tabebuia heterophylla, and Coccoloba uvifera

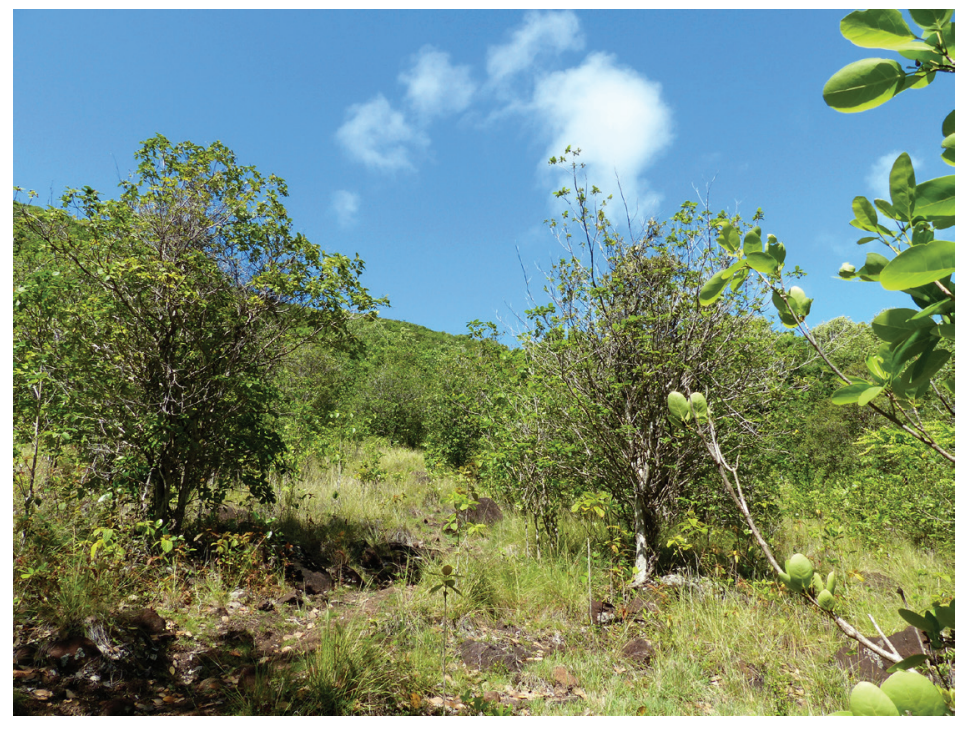

Figure 1. Environment where a skink was observed on Terre-de-Bas (Les Saintes, Guadeloupe) on 9 July 2016.
(Fig. 1). We observed one skink for a few minutes, immobile on a sunny spot at the top of a stone in a small patch of vegetation (15.865, -61.634, elevation $90 \mathrm{~m})$.

The skink moved and disappeared in the vegetation before we could take a photo, but it was similar in size and color (copper-colored) to Mabuya desiradae (Hedges \& Conn, 2012) and Mabuya parviterrae (Hedges et al., 2016). We could not find that individual or other specimens later the same day, or the next morning. From this observation, we conclude that skinks still exist on Terre-de-Bas, in addition to the population on Terre-de-Haut, Les Saintes. 


\section{Acknowledgements}

Field work was conducted under the scope of a project to study the conservation of skinks of the French West Indies, hosted by the Association pour l'Étude et la protection des Vertébrés et végétaux des petites Antilles (AEVA), since 2012. We thank the Direction de l'Environnement, de l'Aménagement et du Logement (DEAL) de la Guadeloupe, especially Luc Legendre, for funding and authorizations. We thank Marie France Barré, Marion and Sébastien Trillot, Rose-Marie Gomez, Yoana Faure, Marion Gessner and Thibault Argouges, volunteers of the Association AEVA, for assistance in the field.

\section{References}

Angin B, Gomès R (2015) First report of a skink population on Les Saintes (Guadeloupe, FWI). Caribbean Herpetology, $52,1-2$.

Angin B, Gomès R, Ibéné B (2015) Premières mentions de scinques Mabuya sp sur les îles des Saintes, archipel de la Guadeloupe. Note edited on the website of the Association ASFA (Association pour la Sauvegarde et la réhabilitation de la Faune des Antilles), 3 March 2015, http:// www.faune-guadeloupe.com/. Accessed 19 July 2016.

Gomès R, lbéné B (2015) Première mention d'un scinque (Mabuya sp) à Terre-de-Bas, Les Saintes. Note edited on the website of the Association ASFA (Association pour la Sauvegarde et la réhabilitation de la Faune des Antilles), 20 March 2015, http:// www.faune-guadeloupe.com/. Accessed 19 July 2016.

Hedges SB, Conn C (2012) A new skink fauna from Caribbean Islands (Squamata, Mabuyidae, Mabuyinae). Zootaxa, $3288,1-244$.

Hedges SB, Lorvelec O, Barré N, Berchel J, Diard Combot M, Vidal N, Pavis C (2016) A new species of skink from the Guadeloupe Archipelago (Squamata, Mabuyidae, Mabuya). Caribbean Herpetology, 53, 1-14.

Lazell JD (1973) The lizard genus Iguana in the Lesser Antilles. Bulletin of the Museum of Comparative Zoology, 145, $1-28$. 